\title{
Biodegradation of reactive red M8B by bacterial consortium SpNb1
}

\author{
Bhatt Nikhil ${ }^{*}$ Thummar Sapna and Balapure Kshama \\ Department of Microbiology, Gujarat Vidyapeeth, Sadra, (Dist: Gandhinagar), Gujarat-382320, India. \\ bhattnikhil2114@gmail.com
}

\begin{abstract}
The release of azo dyes into the environment is a concern due to coloration of natural waters and due to the toxicity, mutagenicity of dyes and their biotransformation products. Economical and bio-friendly approaches are needed to remediate dye contaminated waste water from various industries. In this study, a novel bacterial consortium SpNb1 capable of decolorizing RR M8B dye was isolated from the waste water treatment plant in Naroda G.I.D.C. Bacterial consortium SpNb1 was shown to decolorize different reactive, direct, disperse dyes within 7 - 24 hrs with colour removal range from $24.90 \pm 0.03$ to $96.75 \pm 0.04 \%$. The optimum condition for decolorization of RR M8B by SpNb1 was observed in static condition; dye concentration, $300 \mathrm{mgL}^{-1} ; \mathrm{pH}, 7.5$; inoculums size, $3 \% \mathrm{vv}^{-1}$; temperature, $37^{0} \mathrm{C}$. Biodegradaded products of the dye were monitored by UV-visible, and HPTLC, FTIR spectroscopy. Decolorization study of simulated waste water containing reactive dye RR M8B has been studied by Down Flow Fixed Film Reactor with bacterial consortium SpNb1. The performance of the bioreactor was evaluated by monitoring $\mathrm{pH}, \mathrm{ORP}, \mathrm{Chemical}$ Oxygen Demand (COD), \% of decolorization. The COD reduction and colour removal in the range of 72.07 to $82.22 \%$ and $91.20 \pm 0.05$ to $97.82 \pm 0.06 \%$ respectively.
\end{abstract}

Keywords: Bacterial consortium, Biodegradation, Reactive red M8B, Bioreactor, $16 \mathrm{~S}$ rRNA.

\section{Introduction}

The textile industry generally has difficulty in meeting waste water discharge limits, particularly with regard to dissolved solids, ionic salt, $\mathrm{pH}, \mathrm{COD}$, color and heavy metal (Prasad \& Rao, 2010). Treatment of dye contaminated waste water discharged from the textile and other dye stuff industries is necessary to prevent of soil, surface and ground water. The chemical structure of dyes is comprised of conjugated system of double bonds and aromatic structures. All of these structures allow strong $\underline{n}$ $\rightarrow \underline{\square}^{*}$ transitions in the UV-visible area, with high extinction coefficients that allow us to consider these structures dye chromophores. Of all these structures, the azo aromatic one is the most wide spread dye class industry. The effluent of these industries are highly colored and the disposal of these waste into receiving water causes damage to the environment. Various physico-chemical methods ozonation, photo-oxidation, electrocoagulation, activated carbon, froth flotation, reverse osmosis, membrane filtration and flocculation used are less efficient, costly, limited applicability and produce wastes, which are difficult to dispose off (Ponraj et al., 2011). In the current scenario, biotechnological approaches are receiving increased attention worldwide as environmental friendly methods that are becoming increasingly efficient and cost effective for the remediation of dye contaminated wastewater.

Biotransformation of various pollutants is a sustainable way to clean up contaminated environments. These bioremediation and biotransformation methods harness the naturally occurring, microbial catabolic diversity to degrade, transform or accumulate a huge range of compounds including dyes, xenobiotic compound and hydrocarbons. Microbial populations have an amazing and extensive capacity to degrade a variety of organic compounds (Manogari et al., 2008). For Research article CCIndian Society for Education and Environment (iSee) complete mineralization of azo dyes the microbial population forming part of treatment system should be able to work efficiently under both anaerobic and aerobic conditions (Tripathi \& Srivastava, 2011).

The current study was focused on the screening and isolation of bacterial culture from contaminated soil, wastewater and sludge samples, optimizing various operational parameters for maximum decolorization. Further the consortium SpNb1 was applied for laboratory scale Down flow fixed film reactor study.

\section{Materials and methods}

Dyes and chemicals

Reactive Blue 222, Reactive Blue HER, Reactive Yellow 42, Reactive Red M8B, Reactive Blue MR, Reactive Red HE8B, Reactive Red $\mathrm{C}_{5} \mathrm{~B}-5 \mathrm{~L}$, Reactive Red HE75, Direct Black, Direct Brown, Direct Brick red, Direct Red 81, Direct Navy Blue, Black 13, Disperse Black, Red CD Dark used in the study were purchased from Vim Dye Chem and Ganesh Dye Chem, Vatva, Ahmadabad, Gujarat, India. All microbiological media and medium ingredients were purchased from Hi Media Laboratories (Mumbai, India)

Isolation and cultivation of dye decolorizing bacterial consortium

Soil, dye waste water and sludge samples were collected from the effluent treatment plant Naroda, G.I.D.C, Ahmedabad, Gujarat, India were used for isolation of dye decolorizing bacterial consortium by enrichment culture technique using Bushnell Hass Medium (BHM) and yeast extract (YE) amended with dye Reactive Red M8B (RR M8B 100 $\mathrm{mgL}^{-1}$ ) as a sole source of carbon. Dye containing medium $(100 \mathrm{~mL})$ in $250 \mathrm{~mL}$ Erlenmeyer flasks were inoculated with $10 \mathrm{~mL}$ of $1 \%(\mathrm{w} / \mathrm{v})$ soil suspension and incubated on the orbital shaker (150 $\mathrm{rpm}$ ), as well as, under stationary condition at $37^{\circ} \mathrm{C}$. Samples, which showed decolorization in liquid media, "Biodegradation azo dye" http://www.indjst.org
Bhatt Nikhil et al. Indian J.Sci.Technol. 
were repeatedly tested further by adding fresh dye containing medium till stable dye decolorizing culture obtained, showing consistent growth and decolorization in every successive transfer.

Selection of potent bacterial consortium

Bacterial consortium SpNb1 was selected on the basis of its ability to decolorize various reactive, disperse and direct dyes with maximum percentage of decolorization within shorter time period.

\section{Selection of model dye}

RR M8B was selected as a model dye because it is structurally complex and has good market value and high applicability.

\section{Nutrient media}

The microbial consortium SpNb1 was routinely grown at $37^{\circ} \mathrm{C}$ on Bushnell and Hass Medium (BHM) containing the following ingredients in $\mathrm{g} / \mathrm{l}: \mathrm{K}_{2} \mathrm{HPO}_{4}: 1.0 ; \mathrm{KH}_{2} \mathrm{PO}_{4}: 1.0$; $\mathrm{MgSO}_{4}: 0.2 ; \mathrm{FeCl}_{3}: 0.05 ; \mathrm{NH}_{4} \mathrm{NO}_{3}: 1.0 ; \mathrm{CaCl}_{2}: 0.02$. The $\mathrm{BHM}$ was supplemented with $0.5 \%$ YE along with RR M8B (100 ppm).

Identification of bacteria using $16 S$ rDNA sequencing

A 16S rRNA analysis method was used to identify the selected bacterial strains. The nearly full -length $16 \mathrm{~S}$ rRNA gene was amplified by PCR with forward and reversed primal universal. Purified PCR products were sequenced. The sequences were finally assembled to produce nearly full- length sequence and the sequences available in the National Centre Biotechnology Institute. (NCBI) Gene bank data base. The probable identify of the bacterial strain was thus determined. Identification to the species level was defined as a 16S rDNA sequence similarity of $\geq 99 \%$ with that of the prototype strain in Gene bank: identification at the genus level was defined as a $16 \mathrm{~S}$ rDNA sequence similarity of $\geq 97 \%$ with that of the prototype strains in Gene bank. A failure to identify was defined as a 16S rRNA sequence similarity score lower than $97 \%$ with those deposited in gene bank at the time of analysis. (April, 2012). Sequencing of the bacterial strain was conducted by the Gujarat State Biotechnology Mission: GSBTM, Gandhinagar, Government of Gujarat, India.

\section{Decolorization study and quantification}

For the decolorizing study, $3 \mathrm{~mL}$ of uninoculated and inoculated broths were centrifuged at $6000 \mathrm{rpm}$ for $20 \mathrm{~min}$ (REMI C-24 Centrifuge). Supernatant was used to determine decolorization by measuring the change in absorbance at the maximum absorption wavelength $(\lambda$ max) of the respective dyes using UV-visible spectrophotometer (Analytik Jena Spcord 254). The percentage of decolorization was calculated (Saratale et al., 2009)

\section{Optimization of culture conditions for efficient decolorization}

For achievement of higher decolorization, various physicochemical parameters were studied such as: dye concentration (50-450 mg. $\left.\mathrm{L}^{-1}\right), \mathrm{pH}(6.0-9.0)$, inoculum size $(1-4 \% \mathrm{v} / \mathrm{v})$, temperature $\left(30,35,37,40, \& 45^{\circ} \mathrm{C}\right)$ and
Vol. 5 No. 6 (June 2012)

ISSN: 0974- 6846 the co-substrates such as various carbon sources, nitrogen sources. All the experiments were performed in triplicates.

Analytical procedure for decolorization and degradation analysis: UV-Vis spectral, HPTLC and FTIR

The supernatant sample was used for UV-Vis spectral analysis, HPTLC and FTIR analysis. Spectral analysis was carried out using Analytik jena Specord 254 UV-Vis spectrophotometer and changes in its absorption spectrum (400-800 nm) were recorded. HPTLC analysis was carried out in silica gel using mobile phase solvent system n-propanol: ethyl acetate: water $\left(6: 1: 3 \mathrm{vv}^{-1}\right)$. FTIR analysis was carried out using Perkin Elmer, spectrophotometer and changes in \% transmission at different wavelengths $\left(V \mathrm{~cm}^{-1}\right)$ were observed.

Bioreactor study: Application of consortium on simulated dye waste water

Preparation of simulated dye waste water: A synthetic feed designed to stimulate reactive dye (RR M8B) and was fed to the reactor, with essential nutrients supplied as described below:

The influent feed mainly contained $\mathrm{gL}^{-1}: \mathrm{K}_{2} \mathrm{HPO}_{4}$ (0.5), $\mathrm{KH}_{2} \mathrm{PO}_{4}(0.5), \mathrm{MgSO}_{4}(0.1), \mathrm{FeCl}_{3}(0.025) \mathrm{NH}_{4} \mathrm{NO}_{3}$ (1.0), $\mathrm{CaCl}_{2}(0.01)$ yeast extract $(0.025)$, lactose $(0.15)$ supplemented with $300 \mathrm{mgL}^{-1} \mathrm{RR}$ M8B.

Reactor set up

Biofilm support: Pieces of furnace charcoal $(0.2$ to 1.0 $\mathrm{cm}$ ) were used as biofilm support because of their high porosity. The pieces of furnace charcoal were thoroughly washed with tap water to remove the impurities deposited in cavities, and properly dry at $105^{\circ} \mathrm{C}$ in oven before used as packing materials. Potent bacterial consortium SpNb1 was used as seed inoculum for development of biofilm.

Experimental procedure for down flow fixed film bioreactor: Laboratory scale fixed film down flow reactor was constructed having total volume of $900 \mathrm{~mL}$ (without bedding material) with working volume of $400 \mathrm{~mL}$. The reactor inner diameter is $2.2 \mathrm{~cm}$, reactor height is $27 \mathrm{~cm}$. Reactor was packed with about 880 numbers of furnace charcoal pieces as a bedding material. To initiate biofilm development, $400 \mathrm{~mL}$ of BHM broth grown cell suspension of consortium SpNb1 (initial cell concentration $10^{7}$ cells $\mathrm{mL}^{-1}$ ) was fed to the bioreactor in a loop of 2 days as inoculum for furnace charcoal pieces. This was followed by a feed of simulated waste water for a period of 15 days. The dye concentration was gradually increased from the $100 \mathrm{mgL}^{-1}$ to final concentration 500 $\mathrm{mgL}^{-1}$ within a period of 14 days and then reactor was maintained with RR M8B (500 $\left.\mathrm{mgL}^{-1}\right)$.

Analysis of the effluent: The effluent collected from each successive in takes were analyzed for the parameter such as $\mathrm{pH}$ Oxidation Reduction Potential (ORP), COD, and $\%$ of decolorization. $\mathrm{pH}$ and ORP were measured using digital $\mathrm{pH}$ meter (mKV1 Systronics, India).

The percent COD reduction was determined by monitoring the decrease in COD of bioreactor effluent as
Research article

CIndian Society for Education and Environment (iSee)
"Biodegradation azo dye" http://www.indjst.org
Bhatt Nikhil et al. Indian J.Sci.Technol. 
comparison to bioreactor feed, and then calculated as follows:

$\% \mathrm{COD}$ reduction $=(\mathrm{Ci}-\mathrm{Cf}) \times 100$ $\mathrm{Ci}$

Where, $\mathrm{Ci}=\mathrm{COD}$ of feed of bioreactor

$$
\mathrm{Cf}=\mathrm{COD} \text { of effluent of bioreactor }
$$

Results and discussion

Isolation and cultivation of dye decolorizing bacterial consortium

Isolation of bacterial consortium from soil, waste water and sludge sample were carried out by the enrichment culture technique using RR M8B as a sole source of carbon and energy. But we are not successful in isolating bacterial consortium capable of decolorizing and utilizing only dyes as a sole source of carbon and energy. Decolorization occurred only when growth medium was supplemented with YE. Our results are in accordance with Franciscon et al. (2009) they have reported isolation and screening of microorganisms capable of decolorizing various azo dyes from sludge collected from waste water treatment sites contaminated with dyes.

\section{Selection of efficient bacterial consortium}

A total 7 bacterial consortium were screened by enrichment culture technique. Among them SpNb1 was proved most potent bacterial consortium with maximum $96.75 \pm 0.04 \%$ of decolorization and $13.82 \mathrm{mgL}^{-1} \mathrm{~h}^{-1}$ dye removal rate. In 2009 Khadijah, observed in his experimental studied on dye biodegradation that, higher degree of biodegradation and mineralization can be expected when co metabolic activities within a microbial community complement each other.

Identification of bacteria using $16 S$ rDNA sequencing

The isolation of efficient dye decolorizing bacteria from the samples collected from the dye contaminated soil, wastewater, sludge sample indicates the natural adaptation of these microorganisms to survive in the presence of the toxic dyes.

The nearly full length 16S rRNA gene sequence analysis show that strain designated as $\mathrm{Sb} 2$ to $\mathrm{Sb} 6$ were identified as with their gene sequence similarity value; and belongs to Citrobacter freundii (98.6\%), Bacillus subtilis (97.9\%), Citrobacter freundii (97.5\%), Bacillus flexus (98.8\%), and Citrobacter freundii (97.8\%).

Citrobacter freundii; Accession No: JQ867020; Sample ID: Sb2; BAB ID: 1685

Bacillus subtilis; Accession No: JQ867021; Sample ID: Sb3; BAB ID: 1686

Citrobacter freundii; Accession No: JQ867022; Sample ID: Sb4; BAB ID: 1687

Bacillus flexus; Accession No: JQ867023; Sample ID: Sb5; BAB ID: 1688

Citrobacter freundir; Accession No: JQ867024; Sample ID: Sb6; BAB ID: 1689

Optimization of culture conditions for efficient
decolorization Effect of dye concentration on RR M8B decolorization
Vol. 5 No. 6 (June 2012) ISSN: 0974-6846

The decolorization of the dyes was studied at various increasing initial concentration of RR M8B dye (50-450 $\mathrm{mgL}^{-1}$ ). Results obtained shows complete decolorization of the dye at initial concentration between $50-300 \mathrm{mgL}^{-1}$. Highest decolorization percentage of $90.14 \pm 0.05 \%$ with $27.04 \mathrm{mgL}^{-1} \mathrm{~h}^{-1}$ dye removal obtained within $10 \mathrm{hrs}$. This indicates that an acceptable high colour removal can be achieved with consortium SpNb1 in culture broth with dye concentration $300 \mathrm{mgL}^{-1}$ shown in Fig. 1. Decreased percentage decolorization of dyes obtained at higher concentrations suggests increasing dye toxicity with increase the dosage. Toxic effect was probably due to inhibition of cellular metabolic activities and cell growth.

Waghmode et al. (2012) reported the decolorization and biodegradation at $150-200 \mathrm{mgL}^{-1}$ Rubin GEL concentration by microbial consortium GG-BL. Similar observation have been reported by Ayed et al. (2010) the consortia has ability to degrade higher concentration of dye.

\section{Effect of $p H$ on RR M8B decolorization}

The influence of different $\mathrm{pH}$ on percentage decolorization of RR M8B was also recorded. SpNb1 was compared across a range of $\mathrm{pH}$ (6-9) to achieve maximum decolorization. Our consortium exhibited optimum decolorizing activity with narrow $\mathrm{pH}$ range from 7.0 to 8.0. But the consortium SpNb1 exhibited optimum decolorizing activity at $\mathrm{pH} 7.5$ with maximum dye decolorization $94.95 \pm 0.09 \%$ and $29.98 \mathrm{mgL}^{-1} \mathrm{~h}^{-1}$ dye removal rates within $9.30 \mathrm{hrs}$ at $300 \mathrm{ppm}$ dye concentration as per Fig. 2. Further increase in $\mathrm{pH}$, dye decolorizing activity of the culture was found decreased. This may be related to the transport of dye molecules across the membrane, which is considered a rate limiting step.

Our observed results and finding are in accordance with Phugare et al. (2011) they have studied the bacterial consortia SDS with maximum decolorization and degradation efficiency at $\mathrm{pH}$ 7.0. Similar result was reported by Chaube et al. (2010) that the optimal pH for the mix consortia of bacteria was in narrow range between 7.0 to $8.0 \mathrm{pH}$.

\section{Effect of inoculum size on RR M8B decolorization}

In order to find out the optimum inoculum needed for faster and higher percentage of decolorization by bacterial consortium, decolorizing ability was studied at different inoculum concentrations ranged from 1 to $4 \%$ $\left(v^{-1}\right)$. There was increase in decolorization rate with rise in inoculum concentration. The maximum activity was recorded at $3 \%$ inoculum concentration with $95.25 \pm 0.05$ $\%$ decolorization efficiency and $33.61 \mathrm{mgL}^{-1} \mathrm{~h}^{-1}$ dye removal rates within $8.30 \mathrm{hrs}$ (Fig. 3). Further increase in the inoculum size did not improved decolorization. It might be due to the fact that increase in inoculum size generally improves the growth and growth related activities of bacterial culture, but there could be reduction in dye removal rate due to nutrient limitation.
Research article

(C)Indian Society for Education and Environment (iSee)
"Biodegradation azo dye" http://www.indjst.org
Bhatt Nikhil et al. Indian J.Sci.Technol. 
Indian Journal of Science and Technology

Fig. 1. Effect of dye concentration on RR M8B decolorization

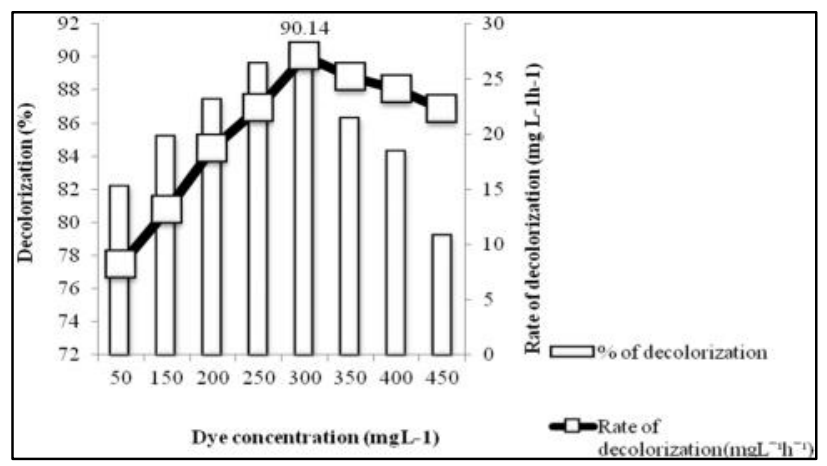

Fig. 2. Effect of $p H$ on RR M8B decolorization

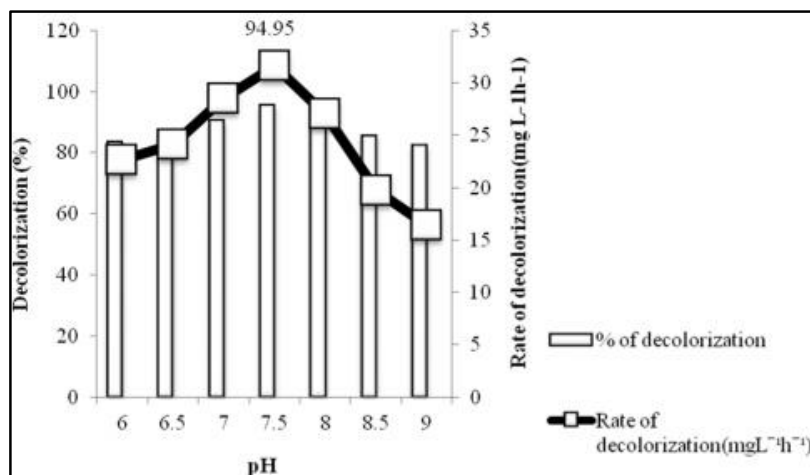

Fig. 3. Effect of inoculum size on RR M8B decolorization

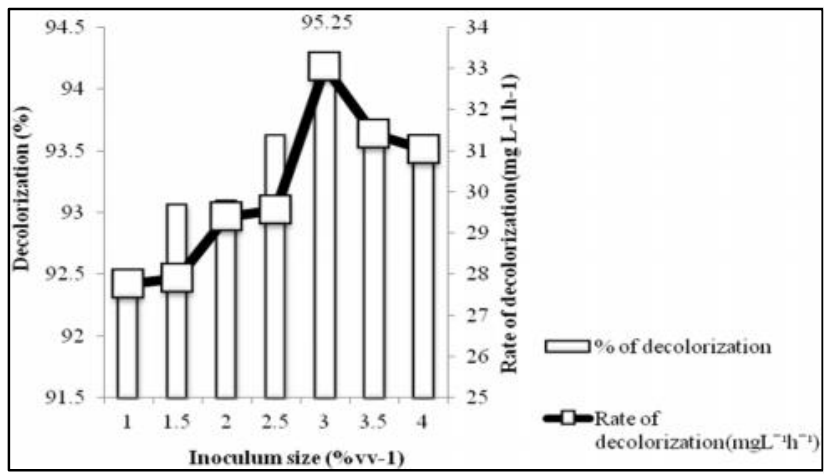

Fig. 4. Effect of temperature on RR M8B decolorization

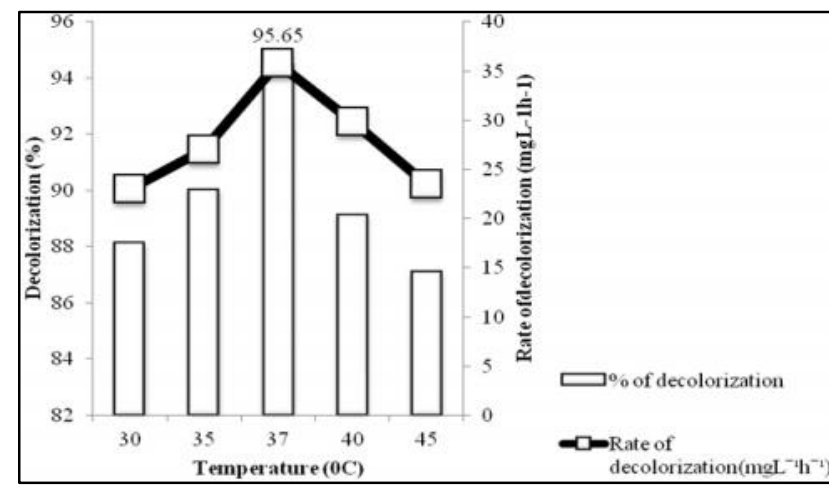

Vol. 5 No. 6 (June 2012)

ISSN: 0974- 6846

Fig. 5. Effect of carbon source on RR M8B decolorization

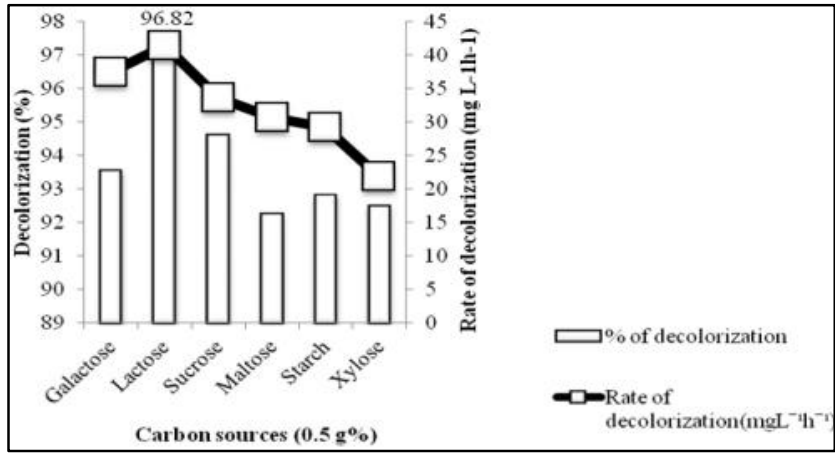

Fig. 6. Effect of nitrogen source on RR M8B decolorization

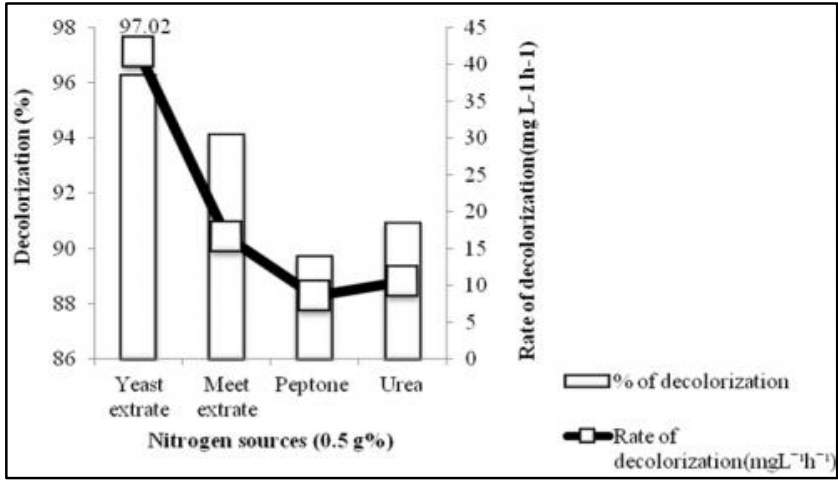

Fig. 7. Spectrophotometric analysis of control (Red Line) RR M8B (300 $\left.\mathrm{mgL}^{-1}\right)$ and decolorized broth (Blue Line)

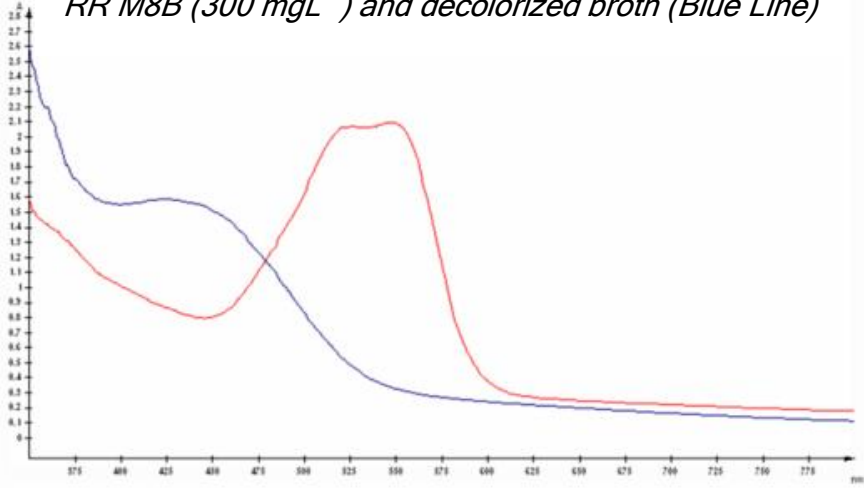

Fig. 8. HPTLC peaks for $1 \%$ stock solution (pink line) control (blue line) and test (light green line) (RR M8B, $300 \mathrm{mgL}^{-1}$ ) at $366 \mathrm{~nm}$ Visible light

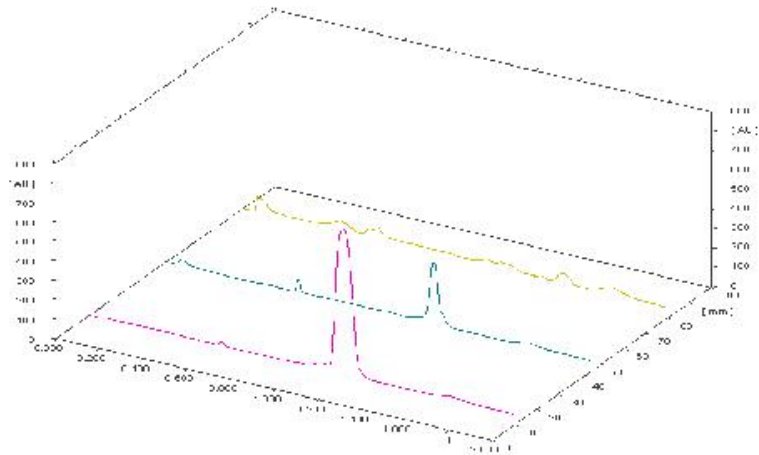

Bhatt Nikhil et al. Indian J.Sci.Technol. 
Vol. 5 No. $6 \quad$ (June 2012) ISSN: 0974- 6846
Table 1. Application of bacterial consortium SpNb1 on structurally different reactive, direct and disperse dyes at $100 \mathrm{mgL}^{-1}$ concentration

\begin{tabular}{|c|l|c|r|c|}
\hline No & \multicolumn{1}{|c|}{ Dyes } & $\begin{array}{c}\text { Time of } \\
\text { Decolorization(hrs) }\end{array}$ & $\begin{array}{c}\% \text { of } \\
\text { decolorization }\end{array}$ & $\begin{array}{c}\text { Decolorization } \\
\text { rate }\left(\mathrm{mgL}^{-1} \mathrm{~h}^{-1}\right)\end{array}$ \\
\hline 1 & RB 222 & 10 & $75.47 \pm 0.02$ & 7.54 \\
\hline 2 & RB HER & 24 & $50.11 \pm 0.08$ & 2.08 \\
\hline 3 & RY 42 & 10 & $45.56 \pm 0.06$ & 4.55 \\
\hline 4 & RR M8B & 7 & $96.75 \pm 0.04$ & 13.82 \\
\hline 5 & RB RGB & 10 & $80.98 \pm 0.07$ & 8.09 \\
\hline 6 & RB MR & 22 & $72.19 \pm 0.06$ & 3.28 \\
\hline 7 & RR HE8B & 23 & $36.05 \pm 0.02$ & 1.56 \\
\hline 8 & RR C5B-5L & 7 & $77.14 \pm 0.06$ & 11.02 \\
\hline 9 & RR HE75 & 9 & $75.77 \pm 0.08$ & 7.97 \\
\hline 10 & $\begin{array}{l}\text { DRECT } \\
\text { BLACK }\end{array}$ & 16 & $93.71 \pm 0.07$ & 5.85 \\
\hline 11 & $\begin{array}{l}\text { DIRECT } \\
\text { BROWN }\end{array}$ & 17 & $24.90 \pm 0.03$ & 1.46 \\
\hline 12 & $\begin{array}{l}\text { DIRECT } \\
\text { BRICK } \\
\text { RED }\end{array}$ & 8 & $63.69 \pm 0.04$ & 7.96 \\
\hline 13 & $\begin{array}{l}\text { DIRECT } \\
\text { RED 81 }\end{array}$ & 7 & $90.08 \pm 0.01$ & 12.86 \\
\hline 14 & $\begin{array}{l}\text { DIRECT } \\
\text { NEAVY } \\
\text { BLUE }\end{array}$ & 24 & $90.82 \pm 0.09$ & 4.03 \\
\hline 15 & BLACK 13 & 7 & $84.83 \pm 0.07$ & 12.06 \\
\hline 16 & $\begin{array}{l}\text { DISPERCE } \\
\text { BLACK }\end{array}$ & 14 & $45.68 \pm 0.06$ & 3.39 \\
\hline 17 & $\begin{array}{l}\text { RED CD } \\
\text { DARK }\end{array}$ & 7 & $93.18 \pm 0.02$ & 13.31 \\
\hline
\end{tabular}

\section{Effect of temperature on RR M8B decolorization}

The study was carried out to evaluate the effect of temperature on decolorization at varying temperature ranged from 30 to $45^{\circ} \mathrm{C}$. The obtained results showed that the maximum $95.65 \pm 0.06 \%$ decolorization was achieved at $37^{\circ} \mathrm{C}$ with 35.86 $\mathrm{mgL}^{-1} \mathrm{~h}^{-1}$ dye removal rate within 8 hrs (Fig. 4). This may be owing to a greater production of enzymes and optimal growth conditions of the bacterial culture for its dye decolonization ability. The decolorization at this optimum temperature may be owing to higher respiration and substrate metabolism. This also demonstrate that decolorization of the dye was through microbial reaction which release on optimal temperature and not by absorption. Further, rise in temperature beyond $37^{\circ} \mathrm{C}$ led to decline in decolorization ability of the culture. This might be due to the loss of cell viability or deactivation of the enzymes responsible for decolorization.

However, our observation on effect of temperature is further strongly supported by the investigation carried out by Saratale et al. (2010) had reported that $37^{\circ} \mathrm{C}$ temperature gave maximum decolorization by bacterial consortium.

Effect of carbon sources on RR M8B decolorization

The co-substrate also acts as an electron biodegradation of orange 2 within range from 1 to $10 \%$. Dafale et al., (2008) reported decolorization of azo dyes and simulated dye bath waste water using microbial consortium at 1 to $5 \%$ inoculum size.

Table 2. Scanning report of HPTLC revealed different peaks and $R_{f}$ values of $1 \% R R M 8 B$, control and degraded products

\begin{tabular}{|c|c|c|c|c|c|}
\hline Sample & Track & $\begin{array}{l}366 \mathrm{~nm} \\
\text { peaks }\end{array}$ & $\begin{array}{l}366 \mathrm{~nm} R \\
\text { values }\end{array}$ & $\begin{array}{l}254 \mathrm{~nm} \\
\text { peaks }\end{array}$ & $\begin{array}{lll}254 \mathrm{~nm} & \mathrm{R}_{f} \\
\text { values } & \end{array}$ \\
\hline \multirow{6}{*}{$\begin{array}{l}1 \% \text { dye } \\
\text { solution }\end{array}$} & \multirow{6}{*}{1} & 1 & 0.67 & 1 & 0.06 \\
\hline & & 2 & 1.09 & 2 & 0.16 \\
\hline & & 3 & 1.30 & 3 & 0.71 \\
\hline & & 4 & 1.76 & 4 & 1.13 \\
\hline & & & & 5 & 1.33 \\
\hline & & & & 6 & 1.80 \\
\hline \multirow{7}{*}{ Control } & \multirow{7}{*}{2} & 1 & 0.16 & 1 & 0.16 \\
\hline & & 2 & 0.65 & 2 & 0.53 \\
\hline & & 3 & 1.33 & 3 & 0.66 \\
\hline & & 4 & 1.76 & 4 & 1.07 \\
\hline & & & & 5 & 1.32 \\
\hline & & & & 6 & 1.47 \\
\hline & & & & 7 & 1.75 \\
\hline \multirow{9}{*}{ Test } & \multirow{9}{*}{3} & 1 & 0.19 & 1 & 6.6 \\
\hline & & 2 & 0.54 & 2 & 13.1 \\
\hline & & 3 & 0.60 & 3 & 36.5 \\
\hline & & 4 & 0.68 & 4 & 27.6 \\
\hline & & 5 & 1.16 & 5 & 35.0 \\
\hline & & 6 & 1.22 & 6 & 8.6 \\
\hline & & 7 & 1.41 & 7 & 0.6 \\
\hline & & 8 & 1.55 & 8 & 14.3 \\
\hline & & 9 & 1.82 & & \\
\hline
\end{tabular}

Research article

CIndian Society for Education and Environment (iSee)

"Biodegradation azo dye" http://www.indjst.org influence of different carbon sources on the decolorization pattern of $\mathrm{RR} M 8 \mathrm{~B}$, the culture broth was supplemented with galactose, lactose, sucrose, maltose, starch and xylose at $0.5 \%$ concentration. The good growth observed with optimum decolorization $96.82 \pm$ $0.06 \%$ and $38.72 \mathrm{mgL}^{-1} \mathrm{~h}^{-1}$ decolorization rates in presence of the effective carbon source lactose within 7.30 hrs (Fig. 5). Addition of carbon source seemed to be effective to promote the decolorization probably due to the preference of the cells in assimilating the added carbon sources over using the dye compound as the carbon source.

Chaube et al. (2010) showed that the mix consortia exhibited maximum decolorization activity in presence of lactose and glucose as compared to sucrose and maltose. Optimum decolorization obtained for decolorization of textile dye stuff by mixed bacterial consortium in presence of lactose (Kapdan et al., 2000).

Effect of nitrogen sources (Replacement of YE) on RR M8B decolorization

The effect of various nitrogen sources on decolorization performance of bacterial consortium was studied by using organic (each of $0.5 \% \mathrm{YE}$, peptone, urea, meat extract) nitrogen sources. Study revealed that the consortium was able to decolorize the dye up to $97.02 \pm 0.09 \%$ with 41.58 $\mathrm{mgL}^{-1} \mathrm{~h}^{-1}$ dye removal rate within $7 \mathrm{hrs}$ (Fig. 6). 
Fig. 9. HPTLC peaks for $1 \%$ stock solution (pink line) control (blue line) and test ((light green line) (RR M8B, $300 \mathrm{mgL}^{-1}$ ) at $254 \mathrm{~nm}$ UV light

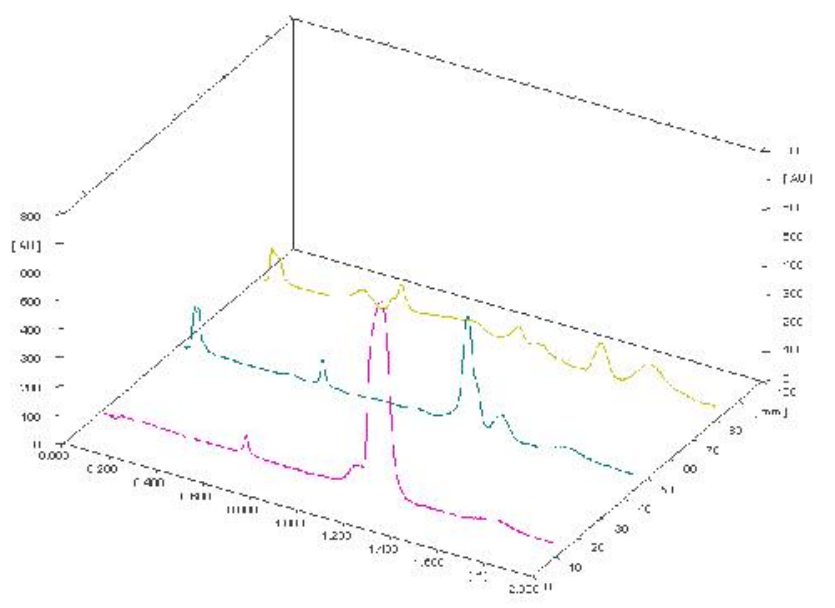

Fig. 10. FTIR spectrum of control RR M8B $\left(300 \mathrm{mgL}^{-1}\right)$

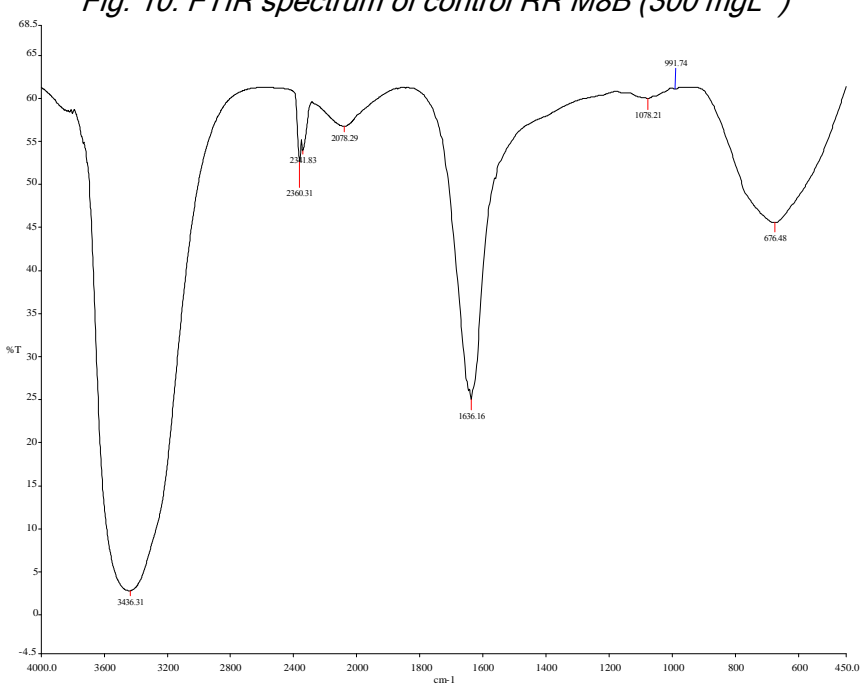

Fig. 11. FTIR spectrum of test RR M8B $\left(300 \mathrm{mgL}^{-1}\right)$

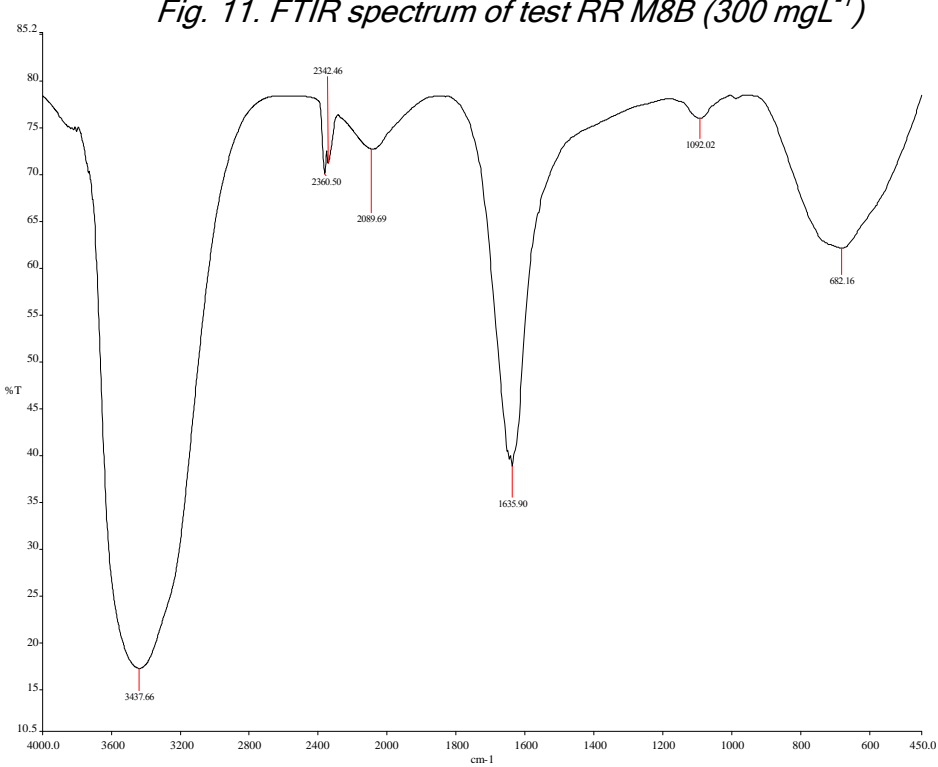

The rate of azo reduction process also depends on the type of co-substrate used and chemical structure of the azo dyes (Vander Zee et al. 2000). The yeast extract medium was most appropriate for the decolorization of $\mathrm{RR} \mathrm{M} 8 \mathrm{~B}$ as compared to other nitrogen sources. This may be owing to the metabolism of yeast extract which is considered essential for the regeneration of $\mathrm{NADH}$ that act as electron donors of the reduction of azo dyes by microorganisms (Khehra et al., 2005).

Jalandoni et al. (2010) carried out the experiment for congo red decolorizing bacterial consortia using yeast extract as a nitrogen source. Moosvi et al. (2007) reported that the bacterial consortium JW-2 gave higher decolorization when medium was supplemented with yeast extract.

Analytical method for decolorization and degradation analysis

Decolorization and biodegradation analysis was confirmed by performing UV-Visible scanning, TLC, HPTLC and FTIR. Spectrophotometric analysis (at 540 $\mathrm{nm}$ ) of inoculation medium containing RR M8B $(300 \mathrm{mgL}$ $\left.{ }^{1}\right)$ showed decrease in the peak as compared to the uninoculated medium (Fig. 7). The HPTLC analysis at different wave lengths (366and $254 \mathrm{~nm}$ ) revealed that both the samples showed the different $\mathrm{R}_{f}$ values it indicates that new metabolic products were formed (Fig. $8-9$ and Table 2).

FTIR analysis was performed to characterize the generated metabolites. In the FTIR analysis, control had different peaks 3436.31 (O-H stretching), 2360.31 and $2341.83\left(\mathrm{R}_{2} \mathrm{NH}_{2} ; \mathrm{R}_{3} \mathrm{NH}\right.$ and $\mathrm{P}-\mathrm{H}$ stretching $), 2078.29$, 1636.16, 1078.21 ( $\mathrm{C}=\mathrm{S}$ stretching), $676.48 \mathrm{~cm}^{-1}$, indicates $\mathrm{C}=\mathrm{C}$ plane bending. While decolorized broth had peaks at $3437.66(\mathrm{~N}-\mathrm{H}$ stretch), 2360.50, 2360.50, $2342.46\left(\mathrm{~N}^{+} \mathrm{H}_{2}\right.$ and $\mathrm{N}^{+} \mathrm{H}$ stretching), $2089.69 \quad(\mathrm{~N}=\mathrm{C}$ stretching), 1635.90, 1092.02 ( $\mathrm{C}=\mathrm{C}$ skeletal stretch), $682.16 \mathrm{~cm}^{-1} m \rightarrow s-m$ indicates disubstituted benzenes (Fig.10-11). The appearance of new peaks and the absence of the peaks representing the azo reductase activity catalysed reduction cleavage of azo bonds of RR M8B supporting biodegradation.

Bioreactor study

Analysis of effluent: In order to find out the applicability of the bacterial consortium SpNb1 was grown as a biofilm on farness charcoal in Down Flow Fixed Film Batch Bioreactor. The reactor was continuously monitored on $\mathrm{pH}, \mathrm{ORP}, \mathrm{COD}$ and \% of decolorization. The results of $\mathrm{pH}$ and ORP were 6.9 to 7.2, ORP -012 to -020 respectively. The bioreactor outflows in different dye concentration ranged from 100 to $500 \mathrm{mgL}^{-1}$ were near to neutral. Effluent $\mathrm{pH}$ values of Reactive blue $\mathrm{H} 3 \mathrm{R}$ and Reactive red HE7B were in the range of $6.8-7.3$ and 6.8 - 7.05 respectively (Manu \& Chaudhri, 2003). A negative value of ORP indicates facultative condition was generated in the reactor. Apart from this the initial COD concentration of influent ranged from (1540 \pm 0.03 to $3550 \pm 0.04)$ after treatment it was reduced up to (430 \pm
Research article

CCIndian Society for Education and Environment (iSee)
Bhatt Nikhil et al. Indian J.Sci.Technol. 
0.07 to $1020 \pm 0.09$ ) at 100 to $500 \mathrm{ppm}$ dye concentration with 72.07 to $82.77 \%$ average COD removal rate. As increase in dye concentration (100 to $500 \mathrm{ppm}$ ) in the reactor the percentage of decolorization was decreased from $97.82 \pm 0.06$ to $91.20 \pm 0.05$. Naimabadi et al. (2009) examined that the colour removal dropped when reactive red 2 concentrations was increased.

\section{Conclusion}

The present study revealed that the isolated bacterial consortium SpNb1 was able to decolorize RR M8B with decolorization efficiency of $97.02 \pm 0.09 \%$ within 7 hrs at $300 \mathrm{mgL}^{-1}$, thus suggesting its application for decolorization of dye bearing industrial wastewaters. It effectively decolorized under static condition various azo dyes, which are commonly used in the industries. Enhanced decolorization was observed in presence of additional lactose and YE as a carbon and nitrogen sources. UV-Visible analysis, TLC, HPTLC and FTIR analysis of extracted products confirmed the biodegradation of RR M8B. The potent bacterial consortium SpNb1 was also efficient for the treatment of simulated dye waste water having COD as high as 1540 \pm 0.03 to $3550 \pm 0.04$ which was further reduced to $430 \pm$ 0.07 to $1020 \pm 0.09$ for the dye concentration. SpNb1 was also showed colour removal of different dyes indicating the biodegradation of complex dyes and applicability of the strain to decolorize and degrade wide variety of industrial dyes. Hence, this bacterial consortium could be utilized for treatment of dye containing wastewater.

\section{References}

1. Ayed L, Harbi B, Cheref A, Bakhrouf A and Achour S (2010) Application of the mixture design to optimize the formulation of active consortia to decolorize azo dye methyl red. Water Sci. Technol. 62(12), 2837-2845.

2. Chan GF, Noor AR, Lee LK, Siaw YC and Wan LT (2011) Identification and optimization of Novel- 1 bacterial consortium for the biodegradation of orange 2 . Biotechnol. 1(1), 7-16.

3. Chaube $P$, Indurkar $H$ and Moghe $S$ (2010) Biodegradation and decolorization of dye by mix consortia of bacteria and study of toxicity on Phaseolus mungo and Triticum aestivum. Asiatic J. Biotechnol. Resources. 1, 45-56.

4. Dafale N, Rao NN, Meshram SU and Wate RS (2008) Decolorization of azo dyes and simulated dye bath wastewater using acclimatized microbial consortium-biostimulation and halo tolerance. Bioresource Technol. 99, 2552-2558.

5. Franciscon E, Zille A, Dias GF, Ragagnin MC, Durrant LR and Cavaco OA (2009) Biodegaradation of textile azo dyes by a facultative Staphylococcus arlettae strain VN11 using a sequential microaerophilic/aerobic process. Intl. Biodetorioration \& Biodegradation. 63, 280-288.

6. Jalandoni-Buan AC, Decena-Soliven AA, Cao EP, Barraquio VL and Barraquio WL (2010) Characterization and identification of Congo red decolorizing bacteria from monocultures and consortia. Philippine J. Sci. 139 (1), 71-78.
7. Kapdan KI, Kagi F, Mcmullan G and Marchant R (2000) Decolorization of textile dyestuffs by a mixed bacterial consortium. Biotechnol. Letters. 22, 1179-1181.

8. Khadijah O (2009) Isolation, screening and development of local bacterial consortia with azo dyes decolorizing capability. Malasian J. Microbiol. 5(1), 25-32.

9. Khehra MS, Sani HS, Sharma DK, Chadha BS and Chimni SS (2005) Decolorization of various azo dyes by bacterial consortium. Dyes \& Pigments. 67, 55-61.

10. Manogari R, Daniel D and Krastanov A (2008) Biodegradation of rice mill effluent by immobilized Pseudomonas sp. cells. Ecol. Engg. Environ. 1, 30-35.

11. Manu B and Chaudhari S (2003) Decolorization of indigo and azo dyes in semicontinous reactors with long hydraulic retention time. Center for Environ./ Sci. \& Engg. pp: 1213-1221.

12. Moosvi S and Madamwar D (2007) An integrated process for the treatment of CEPT wastewater using coagulation, anaerobic anaerobic and aerobic process. Bioresource Technol. 98, 3384-3392.

13. Naimabadi A, Movahedian HA and Shahsavani A (2009) Decolorization and biological degradation of Azo dye Reactive red 2 by anaerobic /aerobic sequential process. Iranian J. Environ. Health Sci. Engg. 6, 67-72.

14. Phugare SS, Dayanand CK, Shripad NS and Jyoti PJ (2011) Ecofriendly degradation, decolorization and detoxification of textile effluent by developed bacterial consortium. Ecotoxicity \& Environ. Safety. 74, 12881296.

15.Ponraj M, Gokila K and Zambare V (2011) Bacterial decolorization of textile dye ORANGE 3R. Intl. J. Advanced Biotechnol. \& Res. 2, 168-177.

16. Prasad A and Rao KB (2011) Physicochemical analysis of textile effluent and decolorization of textile azo dye by Bacillus Endophyticus strain VITABR13. Environ. Biotechnol. 2, 55-62.

17. Saratale RG, Saratale GD, Chang JS and Govindwar SP (2010) Decolorization and degradation of reactive dyes and dye wastewater by a developed bacterial consortium. Biodegradation. 21, 999-1015.

18. Tripathi A and Srivastava SK (2011) Ecofriendly treatment of azo dyes: Biodecoloriztion using bacterial strains. Intl. J. Biosci., Biochem. \& Bioinfo. 1, 37-40.

19. Vander Zee FP, Lettinga G and Field JA (2000) Chemosphere. 44, 1159-1176.

20. Waghmode TR, Kurade MB, Lade HS and Govindwar SP (2012) Decolorization and biodegradation of Rubine GFL by Microbial consortium GG-BL in sequential Aerobic/ Microaerophilic process. Appl. Bioche. \& Biotechnol. www.ncbi.nlm.nih.gov/pubmad.
"Biodegradation azo dye" http://www.indjst.org
Bhatt Nikhil et al. Indian J.Sci.Technol. 